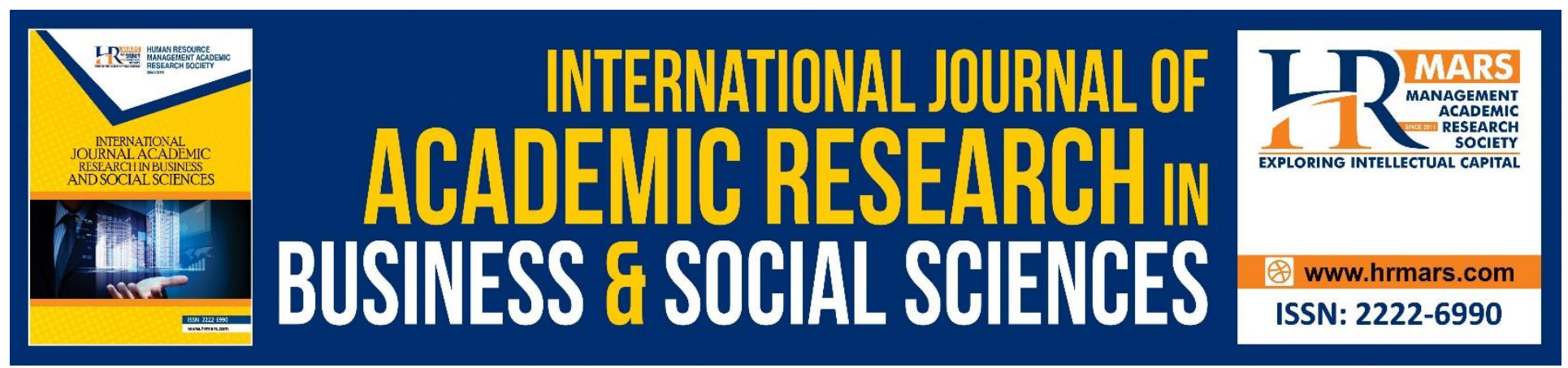

\title{
Organizational Happiness Index (OHI): A Study of a Public University in Malaysia
}

\author{
Muhamad Khalil Omar, Nur Farah Syuhada Mohd Ramdani, \\ Idaya Husna Mohd, Norashikin Hussein
}

To Link this Article: http://dx.doi.org/10.6007/IJARBSS/v8-i11/5562

DOI: $10.6007 /$ IJARBSS/v8-i11/5562

Received: 07 Oct 2018, Revised: 23 Nov 2018, Accepted: 30 Nov 2018

Published Online: 14 Dec 2018

In-Text Citation: (Omar, Ramdani, Mohd, \& Hussein, 2018)

To Cite this Article: Omar, M. K., Ramdani, N. F. S. M., Mohd, I. H., \& Hussein, N. (2018). Organizational Happiness Index (OHI): A Study of a Public University in Malaysia. International Journal of Academic Research in Business and Social Sciences, 8(11), 1984-1994.

Copyright: (C) 2018 The Author(s)

Published by Human Resource Management Academic Research Society (www.hrmars.com)

This article is published under the Creative Commons Attribution (CC BY 4.0) license. Anyone may reproduce, distribute, translate and create derivative works of this article (for both commercial and non-commercial purposes), subject to full attribution to the original publication and authors. The full terms of this license may be seen

at: http://creativecommons.org/licences/by/4.0/legalcode

\section{Vol. 8, No. 11, 2018, Pg. 1984 - 1994}

Full Terms \& Conditions of access and use can be found at http://hrmars.com/index.php/pages/detail/publication-ethics 


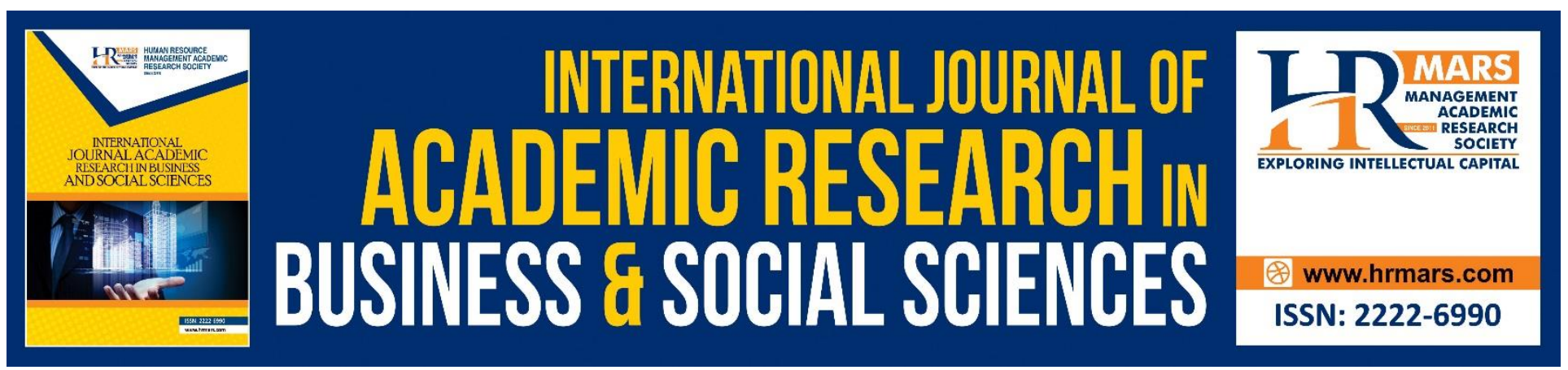

\title{
Organizational Happiness Index (OHI): A Study of a Public University in Malaysia
}

\author{
Muhamad Khalil Omar ${ }^{1}$, Nur Farah Syuhada Mohd Ramdani², \\ Idaya Husna Mohd ${ }^{3}$, Norashikin Hussein ${ }^{4}$ \\ 1,2,3,4 Faculty of Business and Management, Universiti Teknologi MARA, Cawangan Selangor, \\ Kampus Puncak Alam, 42300 Puncak Alam, Malaysia
}

\begin{abstract}
Background: Presently, the issue of happiness in organization has been debated among academicians, practitioners, and policy makers. This is because the concept of happiness is very likely to help guide progress towards sustainable development. Whereas sustainable development entails all parties especially public and private organizations to balance economic, social and environmental objectives in a holistic manner. When organizations pursue economic wealth in an uneven manner, overriding social and environmental objectives, the results often negatively impact human well-being inside and outside organizations such as employees, customers and communities. Thus, organizations are really needed to ensure the sustainability of their development by understanding the level of happiness of their workers. However, evaluating happiness could be indecisive since available measurements were one-dimensional and non-academically validated. Hence, the objective of this study is to test a systematic measurement of organizational happiness index that is conceptualized using 3-dimensional Authentic Happiness theory which was operationalized in one of public university setting as the education industry employ substantial number of human resources. This study aims to quantitatively produce the index for the participating organization besides analyzing the identified research framework using correlational method. The results found only a slightly happy index for the university under study. Therefore, this study can be made reference by academics and practitioners in measuring happiness at workplace based on theoretical-driven scale so that a validated benchmark could be appropriately established. Future research should replicate the same measurement in other setting hence establishing a affirming the feasibility of the index.
\end{abstract}

Keywords: Happiness; Work-Life Balance; Well-Being; Job Satisfaction

\section{INTRODUCTION}

Happiness is increasingly considered a proper measure of social progress and a goal of public policy. Following the historic resolution by the United Nation Assembly initiated by the Prime Minister of Bhutan, the first ever World Happiness Report in 2012 was published and many countries began to 
realize the importance of measuring people's happiness using Gross National Happiness (GNH) index instead of just referring to Gross Domestic Product (GDP) or Gross National Income (GNI) indices towards ascertaining a sustainable development. The GNH index is measured using 9-core domains i.e., psychological well-being, health, time use, education, cultural diversity and resilience, good governance, community vitality, ecological diversity and resilience, and living standard. As per the third World Happiness Report in 2015, Malaysia is currently ranked in 61st place with index of 5.770 out of 10 , hence indicating that Malaysians are on average in the middle, between happy and not happy.

The knowledge of happiness is very important because it enable to sustain development of human capital. Nevertheless in organizational settings, there were no universal indices in measuring happiness especially among employees. At present, many organizations simply measure their employees' happiness using unidimensional measurement e.g. Subjective Happiness Scale (SHS) by Lyubomirsky and Lepper (1999) or by engaging non-theoretically driven scales by various consultants (Paco and Nave, 2013). Only recently the five-dimensional Happy Workplace Index (HWI) developed by Makmee, Kaeodumkoeng, Sinjindawong, Thummakul and Prasertsin (2012) was introduced notwithstanding the lack in the theoretical model and the lack of sound empirical guidance.

Therefore, this study aims to fill these voids by developing an Organizational Happiness Index (OHI) through a theory-driven conceptualization and operationalization modes among employees in a public university of Malaysia. Through this study, an index shall be discovered to benchmark employee happiness and at the same time validating the measurement based on 3-domains of job satisfaction, satisfaction with work-life balance, and employee well-being in a context of education industry.

\section{LITERATURE REVIEW}

\section{Happiness}

According to Veenhoven (2006), the word happiness itself is synonym with well-being and quality of life for every human being. The scholar also stated that there are four qualities of life that someone can work for in order to achieve happiness which are livability of environment, life-ability of the person, utility of life, satisfaction of life. On the other hand, Abraham Lincoln perceptively said that 'most people are as happy as they let themselves be'. This recognizes that there is an individual tendency to a certain level of happiness, however positive psychologists would argue that happiness is not hardwired - only about $25 \%$ as opposed to $40-60 \%$ for most hereditary traits. Rather it is pliable and can change with context. This makes it a particularly crucial issue for organizations. High level of happiness has also extended to workplace experience among employees (Fisher, 2010). In the past two decades, there is number of new ideas or concepts that have been build up that reflect some form of happiness or positive affective experience in the organization. The common things between all of these constructs or ideas is that all refer to pleasant judgments which is positive attitudes or pleasant experiences for instance positive feelings, moods and emotions at workplace. 
INTERNATIONAL JOURNAL OF ACADEMIC RESEARCH IN BUSINESS AND SOCIAL SCIENCES

Vol. 8, No. 11, Nov, 2018, E-ISSN: 2222-6990 @ 2018 HRMARS

\section{Organizational Happiness Index}

There is no universally acceptable measurement of happiness; nor even well-being. But we do know that if each person will define and pursue happiness in her or his own way there will be a few components that will be present for virtually everyone. For example, people tend to want to move toward a changed state, usually a more accomplished one; becoming more capable, more developed as people in whatever domain they choose to devote their time and motivation. They also tend to develop reinforcing social relations whether through a family structure or deliberate choice through friendships and peers. The advantages of measuring happiness in organizational setting are clear for managers. First of all, it provides an index of how well things are going within the organizational context. It is very useful litmus test of the 'climate' and the success of policies and practices in the organization, if the organization able to track well-being and this impacts significantly on organizational performance.

Therefore in this study, based on Authentic Happiness theory by Seligman (2002), the concept of happiness is derived from three distinct domains; the Pleasant Life (Hedonism's sense), The Good Life (Desire's sense), and the Meaningful Life (Objective List's sense). By inferring this theory into organizational setting particularly towards individual employee view, the state of happiness in terms of pleasant in organization could be implied as job satisfaction that could be measured using nine dimensions which are satisfaction with pay, promotion, supervision, benefits, rewards, operating procedures, coworkers, nature of work, and communication (Spector, 1985). On the other hand, the state of happiness in terms of good in organization could be implied as a work-life balance that could be conceptualized based on three dimensions of time, strain, and behavior (Omar, 2013). Finally in terms of meaningful in organization can be regarded as well-being that according to Paschoal and Tamayo (2008), it could be measured by three dimensions which are positive affect, negative affect, and fulfillment. In summary, inferring to an underpinning theory of Authentic Happiness, threedomain measurement of Organizational Happiness Index $(\mathrm{OHI})$ is as shown in Figure 1.

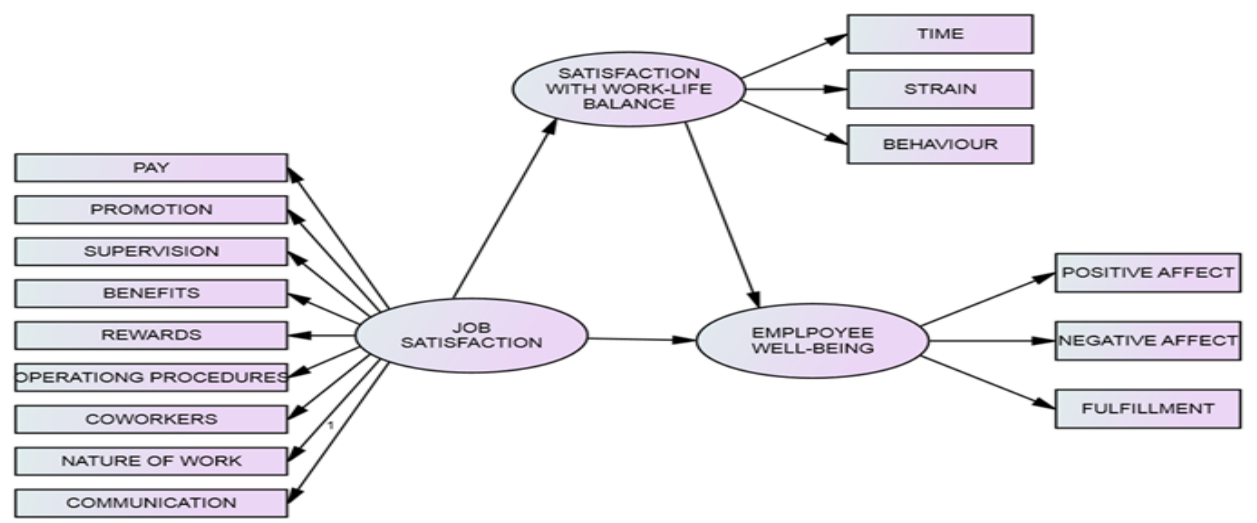

Fig. 1: Framework of Organizational Happiness Index 


\section{Job Satisfaction}

Job satisfaction is a level contentment an individual feel concerning of their job. There is different meaning of job satisfaction according to different scholar. According to Aziri (2011), job satisfaction is the most complicated area that needs to be face by employer especially in managing their employees. Many researcher had make study that job satisfaction really give significant impact on employees motivation, while the level of motivation has an impact on productivity, and consequently likewise on execution of business associations. Many organizations do survey their employees' job satisfaction but satisfaction is only part of a person happiness that is inter-related with other emotional feelings such as balance and well-being as suggested in this study. A study among 893 Malaysian healthcare employees by Omar and Zakaria (2016), found that there was a significant positive relationship between the satisfaction of job and the feelings of balance in work-life interfaces.

\section{Satisfaction with Work-life Balance}

The significant changes in the demographics in modern societies have blurred the boundary and the interactions between work and other life's interests (Dash, Anand, and Gangadharan, 2012). The phrase 'work-life balance' consists of two conjoining requisites; 'work-life' and 'balance'. The first term of 'work-life' encompasses a broad assortment of diverse constructs that include the nexus between paid work and other non-work activities which can be referred to as 'life' (Chang, Mcdonald, and Burton, 2010). This 'work-life' is a broader concept that extends the past studies of 'work-family' with the inclusion of all other life's interests or activities other than family such as leisure, study, recreation, travel, social, community and hobbies. Hence, it reflects the desires of employees with and without families, spouses, children, parents, or other home's needs (Chang et al., 2010). The second term of 'balance' is defined as harmony or equilibrium between two domains, e.g. work and non-work (Comer and Stites-Doe, 2006). This 'balance' was also commonly referred to as the opposite continuum of 'conflict', although there were scarce studies to prove this contention (Valcour, 2007). The concept of work-life balance is also a lot broader in the sense that it is applicable to all employees, irrespective of marital or parental status so that they can experience an effective juggling act between their career and private lives (Dash et al., 2012). On the other hand, argued that it is possible to explore work-life balance trend and development as it influence the employees' wellbeing and job outcomes (Omar and Zakaria, 2015).

\section{Employee Well-being}

Properly diagnose the perceptions of well-being at work and identify its major antecedents consist of relevant issues from both managerial and academic standpoints. Although well-being has received consistent attention from social and organizational researchers (Warr, 2007), the main theoretical proposals and measures focus on general well-being and do not include the well-being in specific contexts, such as at work (Waterman et al., 2010). When investigated in the work context, well-being tends to be assessed by the absence of negative experiences (Luthans, 2002). Moreover, the existence of two main perspectives in the study of well-being, hedonic (affective) and perceptions of fulfillment and personal accomplishment (cognitive), favors the dichotomy between such experiences (Fave, Brdar, Freire, Vella-Brodrick, and Wissing, 2011). As a result of the general well- 
being studies, the organizational literature has started to define and operationalize the well-being at work in either affective or cognitive end fulfillment terms. Authors who adopt an affective approach dealing with the well-being as a cumulative experience of affect at work, defining the phenomenon in terms of emotions and moods of the worker (Horn, Taris, Schaufeli, and Schreurs, 2004). A more cognitive approach of well-being, in turn, emphasizes the experiences of fulfillment and expression of individual potential (Ryan and Deci, 2001). According to Horn et al. (2004), well-being at work is the positive evaluation of various job characteristics comprising emotional, motivational, behavioral, cognitive and psychosomatic aspects.

\section{METHODOLOGY}

In this study quantitative study, the researchers surveyed a public university staffs located in Klang Valley, Malaysia. The convenience sampling was utilized in this study as a standardized questionnaire was developed through online and its link was emailed to all staffs for them to participate voluntarily. The measures of the three domains of $\mathrm{OHI}$ i.e. job satisfaction, satisfaction with work-life balance, and employee well-being will all be adapted from prominent scholars (Paschoal \& Tamayo, 2008; Spector, 1985; Valcour, 2007). The collected data is analyzed using SPSS and all the calculated mean for all three domains of $\mathrm{OHI}$ shall be aggregated to produce the index that shall be referred to indicate the level of happiness for the surveyed organization.

\section{RESULTS AND DISCUSSION}

Table 1 below shows descriptive analysis for demographic among 312 respondents who answered the online questionnaires. About 179 respondents (57.4\%) are female meanwhile the rest of the respondents (42.6\%) are male. The questionnaire also has been distributed to six faculties. Based on Table 2, it shows the mean ranking for all the variables and dimensions for this study. The highest ranking is fulfillment with the value 4.64 , followed by positive affect (4.57) which both of these are under employee well-being. Third ranking is from work-life balance meanwhile the lowest ranking is negative affect. As stated in Table 3, all of these three variables in this study have excellent reliability of the data. Reliability of work-life balance is 0.891 with 36 items which the highest value compares to other two variables. Meanwhile, reliability for job satisfaction is 0.852 with 29 items and employee well-being, 0.881 with seven items. 
INTERNATIONAL JOURNAL OF ACADEMIC RESEARCH IN BUSINESS AND SOCIAL SCIENCES Vol. 8, No. 11, Nov, 2018, E-ISSN: 2222-6990 @ 2018 HRMARS

Table 1: Descriptive Analysis for Demographics

\begin{tabular}{|c|c|c|c|}
\hline Demographic & & Frequency & Percentage (\%) \\
\hline \multirow[t]{6}{*}{ Faculty } & Accountancy & 50 & 16.0 \\
\hline & Health Science & 56 & 17.9 \\
\hline & Hotel \& Tourism & 50 & 16.0 \\
\hline & Pharmacy & 54 & 17.3 \\
\hline & Education & 42 & 13.5 \\
\hline & Architecture, Planning and Surveying & 60 & 19.2 \\
\hline \multirow[t]{2}{*}{ Gender } & Male & 133 & 42.6 \\
\hline & Female & 179 & 57.4 \\
\hline \multirow[t]{7}{*}{ Age } & $21-25$ & 13 & 4.2 \\
\hline & $26-30$ & 74 & 23.7 \\
\hline & $31-35$ & 76 & 24.4 \\
\hline & $36-40$ & 66 & 21.2 \\
\hline & $41-45$ & 45 & 14.4 \\
\hline & $46-50$ & 34 & 10.9 \\
\hline & 51 and above & 4 & 1.3 \\
\hline \multirow[t]{2}{*}{ Marital Status } & Single & 74 & 23.7 \\
\hline & Married & 238 & 76.3 \\
\hline \multirow[t]{3}{*}{ Race } & Malay & 304 & 97.4 \\
\hline & Chinese & 5 & 1.6 \\
\hline & Indian & 3 & 1.0 \\
\hline \multirow[t]{4}{*}{ Religion } & Islam & 306 & 98.1 \\
\hline & Christian & 2 & 0.6 \\
\hline & Buddha & 2 & 0.6 \\
\hline & Others & 2 & 0.6 \\
\hline \multirow[t]{6}{*}{ Highest Education } & SPM & 21 & 6.7 \\
\hline & STPM/Certificate & 17 & 5.4 \\
\hline & Diploma & 51 & 16.3 \\
\hline & Degree & 63 & 20.2 \\
\hline & Master & 103 & 33.0 \\
\hline & $\mathrm{PhD}$ & 57 & 18.3 \\
\hline \multirow[t]{14}{*}{ Hometown } & Johor & 32 & 10.3 \\
\hline & Kedah & 16 & 5.1 \\
\hline & Kelantan & 22 & 7.1 \\
\hline & Melaka & 27 & 8.7 \\
\hline & Negeri Sembilan & 13 & 4.2 \\
\hline & Pahang & 18 & 5.8 \\
\hline & Pulau Pinang & 13 & 4.2 \\
\hline & Perak & 32 & 10.3 \\
\hline & Perlis & 12 & 3.8 \\
\hline & Selangor & 84 & 26.9 \\
\hline & Terengganu & 9 & 2.9 \\
\hline & Sabah & 6 & 1.9 \\
\hline & Sarawak & 6 & 1.9 \\
\hline & Wilayah Persekutuan Kuala Lumpur & 22 & 7.1 \\
\hline \multirow[t]{3}{*}{ Position } & Administrative Staff & 104 & 33.3 \\
\hline & Technician & 51 & 16.3 \\
\hline & Academic Staff & 157 & 50.3 \\
\hline Monthly Gross & Below RM 2000 & 29 & 9.3 \\
\hline \multirow[t]{4}{*}{ Income } & RM 2000 - RM 3999 & 109 & 34.9 \\
\hline & RM 4000 - RM 5999 & 46 & 14.7 \\
\hline & RM 6000 - RM 7999 & 29 & 9.3 \\
\hline & RM 8000 - RM 9999 & 46 & 14.7 \\
\hline
\end{tabular}


INTERNATIONAL JOURNAL OF ACADEMIC RESEARCH IN BUSINESS AND SOCIAL SCIENCES

Vol. 8, No. 11, Nov, 2018, E-ISSN: 2222-6990 @ 2018 HRMARS

\begin{tabular}{llll}
\hline & RM 10000 - RM 11999 & 35 & 11.2 \\
RM 12000 and above & 18 & 5.8 \\
\hline Year of Service & $1-4$ years & 72 & 23.1 \\
& $5-9$ years & 112 & 35.9 \\
& $10-14$ years & 74 & 23.7 \\
$15-19$ years & 31 & 9.9 \\
& $20-24$ years & 19 & 6.1 \\
& 25 years and above & 4 & 1.3 \\
\hline
\end{tabular}

Table 2: Mean Ranking

\begin{tabular}{lll}
\hline Variable/Dimension & Mean & Rank \\
\hline Work-life Balance & 4.55 & 3 \\
\hline Job Satisfaction & & \\
a) Pay & 4.00 & 8 \\
b) Promotion & 3.88 & 10 \\
c) Supervision & 4.29 & 5 \\
d) Benefits & 3.99 & 9 \\
e) Rewards & 3.83 & 11 \\
f) Operation Procedures & 3.46 & 12 \\
g) Coworkers & 4.20 & 6 \\
h) Nature of Work & 4.41 & 4 \\
i) Communication & 4.04 & 7 \\
\hline Employee Well-being & & \\
a) Positive Affect & 4.57 & 2 \\
b) Negative Affect & 3.09 & 13 \\
c) Fulfillment & 4.64 & 1 \\
\hline
\end{tabular}

Table 3: Reliability Analysis

\begin{tabular}{llllll}
\hline & Variable & Value & Item & Mean & Standard Deviation \\
\hline 1 & Work-life Balance & 0.891 & 36 & 4.552 & 0.604 \\
2 & Job Satisfaction & 0.852 & 29 & 4.023 & 0.525 \\
3 & Employee Well-being & 0.881 & 7 & 3.977 & 0.468 \\
\hline
\end{tabular}


INTERNATIONAL JOURNAL OF ACADEMIC RESEARCH IN BUSINESS AND SOCIAL SCIENCES Vol. 8, No. 11, Nov, 2018, E-ISSN: 2222-6990 @ 2018 HRMARS

Table 4: Organizational Happiness Index $(\mathrm{OHI})$

\begin{tabular}{lcc}
\hline \multicolumn{1}{c}{ Variable/Dimensions } & Happiness Index & Indicator \\
\hline Work-life Balance & $\mathbf{6 . 0 9}$ & Slightly happy \\
\hline Job Satisfaction & 6.42 & Slightly happy \\
a) Pay & 5.58 & Neither happy nor unhappy \\
b) Promotion & 6.39 & Slightly happy \\
c)Supervision & 6.24 & Slightly happy \\
d) Benefits & 5.68 & Neither happy nor unhappy \\
e) Rewards & 6.88 & Slightly happy \\
f) Operation Procedures & 5.97 & Slightly happy \\
g) Co-workers & 6.32 & Slightly happy \\
h) Nature of Works & 7.07 & Slightly happy \\
i) Communication & 7.63 & Happy \\
\hline Employee Well-being & 6.62 & Slightly happy \\
a) Positive Affect & 5.72 & Slightly happy \\
b) Negative Affect & 6.62 & Slightly happy \\
c) Fulfillment & 7.63 & Happy \\
\hline OHI & 6.47 & Slightly happy \\
\hline
\end{tabular}

Based on Table 4, the value for happiness index for work-life balance was 6.09 that indicated as slightly happy. For pay, the value was 5.58 that indicate employees were feeling neither happy nor unhappy which was equal to benefits (5.68). However, the respondents were happy with their nature of works (7.07) and communication (7.63) in their workplace. Overall happiness index for job satisfaction was 6.42 which indicated as slightly happy. As same as employee well-being, the indicator also same which was slightly happy and one of its dimensions which were fulfillment (7.63) had higher index as compared to other dimensions. Taken together all the dimensions of work-life balance, job satisfaction and employee well-being, the overall $\mathrm{OHI}$ for this public university is at 6.47 which indicate employees were slightly happy working there. To further analyze whether there were significant relationship between all the domains in this $\mathrm{OHI}$, a correlation analysis was conducted. Based on Table 5, there were positive and significant correlations between all of the domains or variables of $\mathrm{OHI}$.

Table 5: Correlation Analysis

\begin{tabular}{lccc}
\hline & Work-life Balance & Job Satisfaction & Subjective Well-being \\
\hline Work-life Balance & $(0.891)$ & & \\
Job Satisfaction & $.026^{* *}$ & $(0.852)$ & \\
Employee Well-being & $.052^{* *}$ & $.049^{* *}$ & $(0.881)$ \\
\hline
\end{tabular}

\section{CONCLUSION}

In summary, employees of the surveyed organizations were feeling slightly happy working in this public university. This could be the current benchmark before any activities to increase happiness level of employees being implemented. The employer could now be mindful in which domain or particular area it could focus to enhance the employees' happiness. For example in the studied 
organization, the employer could take action to improve the employees' happiness in terms of their pay and benefits because that would be the lowest index. After improvement activities or initiatives being implemented, the organization could run again the survey for this $\mathrm{OHI}$ so that it would determine whether the index has increased or not in order to create and maintain healthier, happier and more productive workplaces. Thus, organizations are well advised to place more emphasis on positive psychology.

In conclusion, findings of this study are significant as they provide both practical and theoretical implications. From a practical standpoint, the results validate the measurement that is theoretically conceptualized and could be implemented as a benchmark to assess happiness level intra and interorganization so that operating issues would be fully understood in order to progress effectively in competitive environment. By knowing this information, policy makers, practitioners and other relevant parties can work synergistically to design specific and structured interventions such as awareness campaign to promote happiness in Malaysia. The index could also be used as a reference to rank employers as the government is planning to produce a generation that well aware of the importance of happiness in their lives so that a sustainable development could be materialized thus allowing the government to set standards for sustaining better quality life.

\section{ACKNOWLEDGEMENT}

Special dedication to the Institute of Research Management \& Innovation (IRMI), Universiti Teknologi MARA for the support and grant awarded to materialize the success of the research endeavor (File No: 600-RMI/RAGS 5/3 (31/2015).

\section{REFERENCES}

Aziri, B. (2011). Job satisfaction: A literature review. Management Research and Practice, 3(4), 7786.

Chang, A., Mcdonald, P., \& Burton, P. (2010). Methodological choices in work-life balance research 1987 to 2006: A critical review. The International Journal of Human Resource Management, 21(13), 2381-2413. doi: 10.1080/09585192.2010.516592

Comer, D. R., \& Stites-Doe, S. (2006). Antecedents and consequences of faculty women's academicparental role balancing. Journal of Family Economic Issues, 27, 495-512. doi: 10.1007/s10834006-9021-z

Dash, M., Anand, V., \& Gangadharan, A. (2012). No Title. IUP Journal of Organizational Behavior, 11(1), 51-65.

Fave, A. D., Brdar, I., Freire, T., Vella-Brodrick, D., \& Wissing, M. P. (2011). The eudaimonic and hedonic components of happiness: Qualitative and quantitative findings. Social Indicators Research, 100, 185-207. doi: 10.1007/s11205-010-9632-5

Fisher, C. D. (2010). Happiness at work. International Journal of Management Reviews, 12, 384-412. doi: 10.1111/j.1468-2370.2009.00270

Horn, J. E., Taris, T. W., Schaufeli, W. B., \& Schreurs, P. J. G. (2004). The structure of occupational wellbeing: A study among Dutch teachers. Journal of Occupational and Organizational Psychology, 77, 365-375. doi:10.1348/0963179041752718 
INTERNATIONAL JOURNAL OF ACADEMIC RESEARCH IN BUSINESS AND SOCIAL SCIENCES

Vol. 8, No. 11, Nov, 2018, E-ISSN: 2222-6990 @ 2018 HRMARS

Luthans, F. (2002). The need for and meaning of positive organizational behavior. Journal of Organizational Behavior, 23(6), 695-706. doi: 10.1002/job.165

Lyubomirsky, S., \& Lepper, H. S. (1999). A measure of subjective happiness: Preliminary reliability and construct Validation. Social Indicators Research, 46(2), 137-155.

Makmee, P., Kaeodumkoeng, K., Sinjindawong, S., Thummakul, D., \& Prasertsin, U. (2012). Development of happy workplace index in private organization by size of organizations in context of Thailand. International Journal of Multidisciplinary Thought, 2(3), 395-401.

Omar, M. K. (2013). Nonstandard work arrangements and affective commitment: The mediating role of work-life balance. Procedia - Social and Behavioral Sciences, 107, 4-12. doi: 10.1016/j.sbspro.2013.12.392

Omar, M. K., \& Zakaria, A. (2015). Conceptualising work-life balance; Extension of work-family balance. Advanced Science Letters, 21(6), 2155-2158. doi: 10.1166/asl.2015.6240

Omar, M. K., \& Zakaria, A. (2016). Work-life balance and job satisfaction among Malaysian healthcare employees. Environment-Behaviour Proceedings Journal, 1(4), 271-278. DOI: 10.21834/ebpj.v1i4.177

Paco, A., \& Nave, A. C. (2013). Corporate volunteering. A case study centred on the motivations, satisfaction and happiness of company employees. Employee Relations, 35(5), 547-559. doi: 10.1108/ER-12-2012-0089

Paschoal, T., \& Tamayo, A. (2008). Construção e validação da escala de bem-estar no trabalho. Avaliação Psicológica, 7(1), 11-22.

Ryan, R. M., \& Deci, E. L. (2001). On happiness and human potentials: A review of research on hedonic and eudaimonic well-being. Annual Review of Psychology, 52, 141-166.

Seligman, M. E. P. (2002). Authentic happiness: Using the new positive psychology to realize your potential for lasting fulfillment. New York: Free Press.

Spector, P. E. (1985). Measurement of human service staff satisfaction: Development of the job satisfaction survey. American Journal of Community Psychology, 13(6), 693-694. doi: 10.1007/BF00929796

Valcour, M. (2007). Work-based resources as moderators of the relationship between work hours and satisfaction with work-family balance. Journal of Applied Psychology, 92(6), 1512-1523. doi: 10.1037/0021-9010.92.6.1512

Veenhoven, R. (2006). How do we assess how happy we are? Tenets, implications and tenability of three theories. In New Directions in the Study of Happiness: United States and International Perspectives (pp. 1-28).

Warr, P. (2007). Work, happiness and unhappiness (1st Editio). New York: Psychology Press. doi: $10.4324 / 9780203936856$

Waterman, A. S., Schwartz, S. J., Zamboanga, B. L., Ravert, R. D., Williams, M. K., Agocha, V. B., Donnellan, M. B. (2010). The questionnaire for eudaimonic well-being: Psychometric properties , demographic comparisons and evidence of validity. The Journal of Positive Psychology, 5(1), 41-61. doi: 10.1080/17439760903435208 